\title{
Historical and Cultural Background in Street Naming System: An Anthropolinguistic Study
}

\author{
Prihadi Ari Listiyorini \\ Teaching Staff at the Department of Indonesian Language and Arts, Faculty of Languages and Arts, Yogyakarta \\ State University, 55281
}

The research is financed by DIPA UNY nomor 45/Penel.UPT-UNY-DIPA/UN34.21/2018

\section{Abstract}

This study aims to depict the history and culture that serve as the background of street naming in Yogyakarta as a part of the distinctive traits of the Yogyakarta Special Region. This is a descriptive research located and limited in the city of Yogyakarta with officially established street names as the research data. The sources of data are both verbal and non-verbal, while the data collection technique includes observation, interview, and recordkeeping. The data were analyzed using the historical cultural approach, while the validity was ensured using data and method triangulations. The findings reveal that street naming is based on historical and cultural studies, with certain motivation, purpose, and background. There are 26 historical and cultural aspects found as the background of street naming in Yogyakarta, dominated by three main aspects, namely plant, Javanese royalty, and type of profession. The motivation and purpose of street naming are to serve as a reminder for the public, while the background for the motivation and purpose is to allow people to find and identify locations and define the scope of the street itself.

Keywords: street naming, anthropolinguistic

DOI: $10.7176 /$ RHSS/9-18-04

Publication date:September $30^{\text {th }} 2019$

\section{Introduction}

There have been many studies on street naming or onomastics on various businesses such as hotels, shops, and restaurants, as well as other places such as villages, housing complex, and objects like food. From the previous onomastics studies, the linguistic aspects (language forms) used are examined, in addition to the historical and cultural aspects, motivation and purpose, and the background for the motivation and purpose of the street naming. This is because language is always related to its community of users. Language is closely related to culture, which involves ideas, behaviors, and the works of human. Language and culture are two sides of the same coin. The same notion applies in the naming process and a certain cultural system (Prihadi, 2015:3).

There is a tendency among the various onomastics studies in Indonesia, which is that most of them examine the incorporation of English in the naming process. For example, Sundari (2008) studies the reasons that business owners use the foreign language. Some think that the use of English simply make their businesses more modern and sophisticated, while others feel that they can attract more customers.

The tendency to use foreign language/English in the naming process seems to not apply with geographical sites or street names. A study done on village naming in Yogyakarta (Prihadi, 2015) finds that none of the villages have foreign names. On the contrary, most of the village names represent the geographical conditions or public figures, in addition to the history and culture of the people at the time. From the village names, it can be learned that there are in fact differences between the theoretical foundation of the sociocultural condition of the community with all of its local wisdom and the actual village naming data in the field.

From the preliminary observation on how the place naming also reflects the social and cultural state of the community, it can be assumed that the street naming in Yogyakarta also does the same. There are many streets in Yogyakarta that reflects the social and cultural condition of the community at the time, e.g. Batikan Street, Kemasan Street, and Jlagran Street. The naming of the three streets is related with the occupation of the community residing in the street, namely Batik craftspeople, goldsmiths, and jlogro or headstone makers, respectively. In comparison, Affandi Street is named after a prominent cultural figure in Yogyakarta.

Various aspects can be seen from the street naming in Yogyakarta, namely the linguistic, historical and cultural aspects, as well as the history and culture of community related to the distinctive trait of the Yogyakarta Special Region. In relation to that, the focus of the current research is street naming based on anthrophonym or history-culture. The street names can be used to view the people of Yogyakarta from various perspectives with all of their distinctions. As stated in the Law of the Republic of Indonesia Number 13 Year 2012 on the Distinction of the Yogyakarta Special Region Chapter 9 Article 31 Section 1 on culture, cultural authority is implemented in order to preserve and develop the results of creation cipta, rasa, karsa, and karya, in the form of values of knowledge, norms, customs, objects, arts, and the noble tradition that are rooted in the people of Yogyakarta. The street naming in Yogyakarta is one of the ways of preserving and developing the culture.

In relation to the distinction of Yogyakarta Special Region, in 2013, some of the main roads in Yogyakarta 
are restored into their original names, namely Trikora Street, Ahmad Yani Street, and Pangeran Mangkubumi Street, which are renamed as Pengurakan Street, Margomulyo Street, and Margoutomo Street. The reason for the street renaming is because Sri Sultan Hamengkubuwono X aims to return the street names according to their philosophical foundations, and means no disrespect to the new names. In addition to the three streets, there will be hundreds of streets that will be renamed to show the distinction of the Yogyakarta Special Region. The change in the street names is aimed to reestablish the spirit of the Yogyakarta Special Region. It is hoped that the next generation will be able to understand and reminisce the noble cultural values of Yogyakarta.

Nevertheless, there is an interesting aspect in the street naming in Yogyakarta. Although several streets have been renamed into their original names in order to represent the distinction of Yogyakarta Special Region, there are in fact new street names that incorporate the history and culture of West and East Java. For example, the Majapahit Street and Padjajaran Street located in the ringroad. The renaming is based on the Decree of the Governor of Yogyakarta Special Region Number 166/KEP/2017 and certainly relates to the current social and cultural state of the people ofYogyakarta with certain motivation and purposes, as well.

The research on the street naming in Yogyakarta is definitely interesting to observe and examine to learn the social and cultural state of the people as well as the province with special distinction. Through the research, it is expected that both the current and next generation can learn about the philosophy, history, and social cultural state of the Yogyakarta people as a whole.

\section{Literature Review \\ Anthropolinguistic}

Anthropolinguistic is an interdisciplinary study between two disciplines, namely anthropology and linguistic. This study is developed to examine the relation between culture and language. This greatly helps many researchers, whether culture or language researchers, as there is an undeniably inseparable relation between language and culture. Anthropolinguistic is a linguistic branch that lays emphasis on the use of language in a wider social and cultural context and the role of language in developing and maintaining the cultural acticity and social structure (Suryatna, 1996:59). In this context, anthropolinguistic views language based on essential anthropolinguistic concept and through culture, finds meaning behind the use, as well as finds the language form, register, and style.

Anthropolinguistic highlights the relation between language and culture in a community (Sibarani, 2004:50). Language that becomes the subject of anthropolinguistic studies according to Duranti (1997:6) is language in its relation between meaning and form of language, which is similar to semantics, except that in anthropolinguistic, such relation is studied based on the cultural perspective in which the language of a person represents his or her culture.1.1 Heading 2

\section{The Relation between Language and Culture}

Essentially, language is a system of symbol of sound that is arbitrary, productive, dynamic, and humane (Chaer dan Agustina, 1995: 14). In accordance with the last feature, language is highly important for humans' lives as they use it to communicate with each other, to think, to express their feelings, and even to dream. Language is one of the signs of civilization for humankind, along with regulations, customs, etc. (Soeseno, 1988: 1).

Language is a part of culture. Koentjaraningrat (1986: 180) states that culture is the entirety of systems of human ideas, behavior, and creation of human in order to create a social life that is made personal through learning. The forms of culture can be ideas, values, regulations, activities, human behavior patterns in the society, and the objects of human creation (Koentjaraningrat, 1986: 186- 187). Culture can be divided into 7 elements that exist in every community in the world, i.e. (1) language, (2) knowledge, (3) social organization, (4) life eqipment/tool system and technology, (5) livelihood/occupation system, (6) religious system, and (7) arts (Koentjaraningrat, 1986: 203:204).

From Kontjaraningrat's definition, it is implied that there is a relation between language and culture. Something spoken through language is a symbol of a real world that can be seen in a concrete manner, as well as the depiction of other abstract concepts. Language is also the main tool for humans to think and express their ideas. Through language, it can be learned how humans live, think, produce knowledge and concepts about their world, then express them in both verbal and non-verbal manners. In short, language is the sign of the knowledge treasure of how a nation conceptualizes their world (Liliweri, 1994).

Kramsch (1998: 3) mentions three things on the relation between language and culture. The words spoken by humans refer to their experience. Humans reinstate their reality or idea that they can communicate by referring to a certain amount of knowledge on the world. Words can also reflect their beliefs and attitudes, their views, and others. Secondly, language creates or brings forth or realizes culture. This is apparent from the medium they choose to communicate, such as the telephone, letters, emails, or newspapers. The methods that they use to speak, write, or communicate through visual media create meanings that their group understand; for instance through the tone of voice of the speaker, the accent, conservative style, gesture, and facial expression. 
Through all the verbal and non-verbal aspects, language creates culture. Lastly, language works as a cultural symbol, which relates to language as the symbol system. The speaker identifies themselves and others as their language. They view language as the symbol of their social identity.

Language is closely related to world view. Palmer (1996: 113) states that "world view cannot be understood without language. It is fundamentally produced by linguistically mediated human thought." From the statement, it is clear that it is impossible to understand the perspective of the world withough language as world view represents the complexity of life itself.

\section{Onomastics and Onomastics Research}

In the Great Dictionary of the Indonesian Language (KBBI, 2015:799), onomastics is defined as a scope of study on the origins of name, form, and meaning (especially people or place). Name is a product of society that can explain various things about society.

Various studies that have been done in relation to onomastics by foreign linguists can be broken down as follows. The first is a study entitled Kandahar of the Arab Conquest conducted by S.W. Helms published in World Archaelogy, Vol. 14, No. 3, Islamic Achaelogy, 1983. This study uses the historical and etymological paradigms to trace the origins of city/place names. Another study entitled California Place Name Record revealed that the city "Kandahar" is now called the city "Alqownloadar". The name of the city is derived from the name of the ruler of the city, namely "Al Baradhuri" who died after drinking baladnur juice. Etymologically, the city name "Kandahar" has several translations, despite having no meaning at all. The name of the city "Kandahar" was given by Alexander the Great as "Kandahan" or "Qondahar" has been rejected. The root word "kand" or "kund", which is used as the name in Central Asia, means "simple place." The naming comes from Avestas literature "Fortress", derived from "kan" (digging), or "kand" (fortress). The formulation of the name is related to historical Islamic stories. Another research conducted by Katherine Karpenstin was published in Western Folklore, Vol. 12, No. 2, 1953. The research was about naming of California. In the study it was stated that California's naming process could be divided into four phases, namely 1) Indian exploration phase, 2) Imaginary geography of the Spanish rule, 3) Mexican period, and 4) American period. In addition, F. Rainey conducted a study entitled The Toponymies of Eretz-Israel published in Bulletin of the American School of Oriental Research, No. 231, 1978, which outlines that onomastical analysis is carried out with 1) structural analysis and 2) semantic analysis. It was further stated that linguistic analysis can be used to identify ancient place names.

\section{Onomastics from the Linguistic Perspective}

A theory first initiated by Cristopher Ehret in an article entitled "Linguistics evidence and its correlation with archaeology" published in Archaelogy and Linguistics Volume 8 No. 1 Year 1975 states that the science in naming a place is an additional part in the historical linguistic science. There are two main functions on the evidence of place naming, namely 1) identifying the first verbal language of a region from the time they initially name the region to the point where they let other languages in; and 2) identifying the etymological functions.

As the street names researched are in Javanese (most of them are words), the street name analysis is based on Javanese morphology, which focuses on the discussion on words, their changes, and the impacts of the changes on the form and meaning. The change assumes three forms at the least, namely (1) the change in the basic form or root, (2) the specific ways of change, and (3) the new words resulted from the change (Subroto, 1990: 15). Next, the morphology process is distinctive in three aspects, namely (1) the order of the change process with the same tools; (2) creating a new component of meaning on the generated changed word; and (3) the new word as a result of change in the polymorphemic form. The relation between (1), (2), and (3) makes the prediction of word forming possible, which allows for a discussion on the word order.

\section{Onomastics from the Historical-Cultural Perspective}

The cultural mirror can also be realized in cultural art form, namely legends and folklore. For instance, the naming of geographical sites in Jakarta is often based on the legend/history or folklore (as referred to in http://www.budayajakarta.com/idk.php.). For instance, the name of the village Cijantung in the sub-district of Pasarrebo, East Jakarta, is originated from a creek of the Ciliwung River which begins in Areman, near what is now Kelapadua.

\section{Onomastics from the Historical Theory as Referenced in International Journals}

A review by Michael Astour on a research entitled "I Nomi di luogo dei testi di Ebla" by Alfonso, et. al. published in the Journal of the American Oriental Society, Vol. 108, No. 4, in 1988 points out that the toponym index is based on 1) documentation, 2) literary text and geographical name list, 3) graphic issues, 4) phonetics, 5) the suffix, 6) the prefix, 7) the toponym, and anthroponym. According to Alfonso (in Astour, 1988: 144), anthroponym is a study of toponym which aims to investigate the origins of the names of the places through 
historical and cultural study which employ the historical-cultural method.

There are 6 (six) catalogues that are related to the name of a place, namely public figures, positions/jobs, administrative terms, terms related to gods, geographical names.

\section{Special Study on the Onomastics Function in History and Culture (Aspect Classification)}

Borre (1968) in F. Rainey as published in Bulletin of the American School of Oriental Research, No. 231, in 1978, categorizes name of place into 6 groups, namely (1) place with godliness meanings, such as those with the prefix "beth-" such as "bethel" and "bethdragon," (2) toponym of a surname, (3) name of a place that begins with a topographic trait, such as "giba," "gibeah," or "gibean," (4) place that is associated with the works of human such as "gorren" and "addar," (5) place with a name of animal that lives in it, and (6) name of a place derived from plants, such as "abel." Meanwhile, according to the Toponymy of the Bigar Region in the Romanian Barat by Zdenek Salzmann published in Anthropological Linguistic, Vol. 32, No.1/2 in 1999, the places in Bigar are named after various traits, such as (1) hydronym (naming of place related to water or a body of water such as river, lake, strait, etc.); 2) onomym (naming of place related to the soil condition/topography, such as hills, mountains, oronymy, etc.); 3) onomastics as a result of human activity, including village toponym and street name onomastics; 4) landscape toponym (meadow, rice field, or other type of landscape, including toponym of the land owner and those related to the physical features of the land).

\section{Research Method}

This study employs the descriptive research design, which involves the details of linguistic aspects (language form and structure), historical aspect, as well as the history and culture, motivation and purpose, and the reason of street naming in Yogyakarta as a part of the distinctive feature of the Yogyakarta Special Region. This is in line with Djajasudarma's view (2006:16) on how descriptive research aims to depict the features of the data accurately based on the scientific characteristics of the data.

After an observation on several regencies, Yogyakarta was selected as the research site because it was the only city with archives on the street names in comparison to other regencies in the provice such as Sleman Regency, which only had certain road names and not all the street names. Therefore, for the authenticity of the data, Yogyakarta was the only city selected as the research site. The map of the city can be seen below. The research data were the street names in the city of Yogyakarta. The sources of the data were both verbal and nonverbal. Verbal data were obtained from informants, while the non-verbal data were gained from the archives of the Yogyakarta Transportation and Bina Marga Agency consisting of street names, in addition to dictionaries, encyclopedia, folklores, as well as books on history and culture.

Essentially, the researcher becomes the human instrument in this study. In this case, researcher has certain determining criteria on the linguistic aspects in street naming in Yogyakarta. Moreover, both software and hardware were utilized as the research instruments. The hardware involved tape recorder, computer, laptop, color printer, USB flash drive, and stationary for documenting the research data, while the software was the linguistic aspect criteria in street naming in Yogyakarta.

This study employed observation, documentation, interview, reading, and record-keeping as the data collection techniques. The field observation and documentation were done in order to concretely find the data on the street names in Yogyakarta, while interview was used as a technique to collect data from the informants. On the other hand, reading and record-keeping techniques were also employed to collect information on street names from the archives of the government of the city of Yogyakarta, as well as from other text-based documents. From the data presentation, the data were identified, selected, and classified.

On the other hand, the data were analyzed using the historical-cultural technique to investigate the historical and cultural background of the community that the street names in Yogyakarta belong to.

Finally, the validity of the data was checked using the data and method triangulation technique. The data triangulation was done by collecting the data from various sources including direct observation, documentation, and the informants, while the method triangulation was done using various methods in the research involving direct observation, interview, and record-keeping.

\section{Results and Discussion}

The results of the research are summarized in the following table. 
Tabel 2. Summary of Concrete Data of the Street Names in Yogyakarta, the Historical and Cultural Study, the History and Culture, Motivation and Purpose, and the Background of Motivation and Purpose in the Form of Examples and Frequency

\begin{tabular}{|c|c|c|c|c|c|c|}
\hline \multirow{2}{*}{ No. } & \multirow{2}{*}{$\begin{array}{c}\text { Street Name } \\
\text { Sample }\end{array}$} & \multirow{2}{*}{$\begin{array}{c}\text { Description of } \\
\text { the Historical } \\
\text { and Cultural } \\
\text { Analysis }\end{array}$} & \multicolumn{2}{|c|}{$\begin{array}{c}\text { Historical and Cultural } \\
\text { Category }\end{array}$} & \multirow{2}{*}{$\begin{array}{c}\text { Toponym } \\
\text { Motivation } \\
\text { and Purpose }\end{array}$} & \multirow{2}{*}{$\begin{array}{l}\text { Background of } \\
\text { Toponym } \\
\text { Motivation and } \\
\text { Purpose }\end{array}$} \\
\hline & & & $\begin{array}{l}\text { History and } \\
\text { Culture }\end{array}$ & Frequency & & \\
\hline 1. & Notowinatan & $\begin{array}{l}\text { The word "noto" } \\
\text { means "king of } \\
\text { the kings" and } \\
\text { the suffix "-an" } \\
\text { means } \\
\text { "place/region." }\end{array}$ & $\begin{array}{l}\text { Name of a } \\
\text { Yogyakarta } \\
\text { Palace royalty }\end{array}$ & $\begin{array}{c}15 \\
(11.5 \%)\end{array}$ & $\begin{array}{l}\text { Sign of a } \\
\text { member of the } \\
\text { royalty as a } \\
\text { form of } \\
\text { respect }\end{array}$ & $\begin{array}{l}\text { To inform the } \\
\text { public that the } \\
\text { street is named } \\
\text { after a royal } \\
\text { from the } \\
\text { Yogyakarta } \\
\text { Palace. The } \\
\text { name is used as } \\
\text { a street name to } \\
\text { pay respect } \\
\text { supaya jadi } \\
\text { petanda } \\
\text { (tetenger: Jw.) }\end{array}$ \\
\hline 2. & $\begin{array}{l}\text { Tegal } \\
\text { Lempuyangan }\end{array}$ & $\begin{array}{l}\text { The suffix "-an" } \\
\text { in } \\
\text { "lempuyangan" } \\
\text { means "place," } \\
\text { while } \\
\text { "lempuyang" is a } \\
\text { type of medicinal } \\
\text { herb. }\end{array}$ & Name of a plant & $\begin{array}{c}22 \\
(16.9 \%)\end{array}$ & $\begin{array}{l}\text { Sign of a } \\
\text { certain type of } \\
\text { herb in an area }\end{array}$ & $\begin{array}{l}\text { To mark a } \\
\text { certain type of } \\
\text { tree/plant } \\
\text { growing in an } \\
\text { area }\end{array}$ \\
\hline 3. & $\begin{array}{l}\text { I Dewa } \\
\text { Nyoman Oka }\end{array}$ & $\begin{array}{l}\text { A fallen soldier } \\
\text { from Bali in the } \\
\text { attack on the } \\
\text { Japanese base in } \\
1945\end{array}$ & $\begin{array}{l}\text { Name of a } \\
\text { historical figure }\end{array}$ & $\begin{array}{c}7 \\
(5.3 \%)\end{array}$ & $\begin{array}{l}\text { Sign of a } \\
\text { significant } \\
\text { historical } \\
\text { figure for the } \\
\text { local } \\
\text { community }\end{array}$ & $\begin{array}{l}\text { To mark a } \\
\text { significant } \\
\text { historical figure } \\
\text { for the local } \\
\text { community }\end{array}$ \\
\hline 4. & Prau & $\begin{array}{l}\text { Name of a } \\
\text { mountain }\end{array}$ & $\begin{array}{l}\text { Name of a } \\
\text { mountain/river }\end{array}$ & $5(3.8 \%)$ & $\begin{array}{l}\text { Sign of a } \\
\text { topographic } \\
\text { area }\end{array}$ & $\begin{array}{l}\text { To mark the } \\
\text { topography of a } \\
\text { particular area }\end{array}$ \\
\hline 5. & Sukonandi & $\begin{array}{l}\text { The word "suko" } \\
\text { means "like", } \\
\text { while "nandi" } \\
\text { means "the } \\
\text { sacred cow." } \\
\text { "Sukonandi" } \\
\text { means a type of } \\
\text { animal or cattle } \\
\text { that assist in } \\
\text { human activity. }\end{array}$ & Type of animal & $8(6.1 \%)$ & $\begin{array}{l}\text { Sign of the } \\
\text { significance of } \\
\text { a particular } \\
\text { cattle in an } \\
\text { area }\end{array}$ & $\begin{array}{l}\text { To mark the } \\
\text { significance of a } \\
\text { particular cattle }\end{array}$ \\
\hline
\end{tabular}




\begin{tabular}{|c|c|c|c|c|c|c|}
\hline \multirow{2}{*}{ No. } & \multirow{2}{*}{$\begin{array}{l}\text { Street Name } \\
\text { Sample }\end{array}$} & \multirow{2}{*}{$\begin{array}{c}\text { Description of } \\
\text { the Historical } \\
\text { and Cultural } \\
\text { Analysis }\end{array}$} & \multicolumn{2}{|c|}{$\begin{array}{c}\text { Historical and Cultural } \\
\text { Category }\end{array}$} & \multirow{2}{*}{$\begin{array}{c}\text { Toponym } \\
\text { Motivation } \\
\text { and Purpose }\end{array}$} & \multirow{2}{*}{$\begin{array}{l}\text { Background of } \\
\text { Toponym } \\
\text { Motivation and } \\
\text { Purpose }\end{array}$} \\
\hline & & & $\begin{array}{c}\text { History and } \\
\text { Culture }\end{array}$ & Frequency & & \\
\hline 6. & $\begin{array}{l}\text { Umum } \\
\text { Kalipan }\end{array}$ & $\begin{array}{l}\text { Name of a figure } \\
\text { that died in a } \\
\text { historical event. } \\
\text { "Kalipan" is } \\
\text { derived from the } \\
\text { Arabic word } \\
\text { "khalifah," which } \\
\text { means "the } \\
\text { representative or } \\
\text { the person } \\
\text { assigned with a } \\
\text { particular task." }\end{array}$ & Name of a figure & $\begin{array}{c}2 \\
(1.5 \%)\end{array}$ & $\begin{array}{l}\text { Sign of the } \\
\text { residence of a } \\
\text { public figure }\end{array}$ & $\begin{array}{l}\text { To mark the } \\
\text { residence of a } \\
\text { particular public } \\
\text { figure }\end{array}$ \\
\hline 7. & Kemasan & $\begin{array}{l}\text { Many goldsmiths } \\
\text { reside in the area. }\end{array}$ & $\begin{array}{l}\text { Type of } \\
\text { profession }\end{array}$ & $\begin{array}{c}12 \\
(9.2 \%)\end{array}$ & $\begin{array}{l}\text { Sign of the } \\
\text { occupation of } \\
\text { the residents } \\
\text { in an area }\end{array}$ & $\begin{array}{l}\text { To mark the } \\
\text { occupation of } \\
\text { the residents in } \\
\text { an area }\end{array}$ \\
\hline 8. & $\begin{array}{l}\text { Jetis } \\
\text { Pasiraman }\end{array}$ & $\begin{array}{l}\text { "Jetis" means "an } \\
\text { end" or "a } \\
\text { corner," while } \\
\text { "siraman" might } \\
\text { refer to a } \\
\text { traditional } \\
\text { shower because it } \\
\text { is close to a river. }\end{array}$ & $\begin{array}{l}\text { Geographical } \\
\text { feature }\end{array}$ & $6(4.6 \%)$ & $\begin{array}{l}\text { Sign of a } \\
\text { geographical } \\
\text { feature in an } \\
\text { area }\end{array}$ & $\begin{array}{l}\text { To mark a } \\
\text { geographical } \\
\text { feature in an } \\
\text { area }\end{array}$ \\
\hline 9. & $\begin{array}{l}\text { Prof. Dr. } \\
\text { Herman } \\
\text { Yohanes }\end{array}$ & $\begin{array}{l}\text { The street on the } \\
\text { way to UGM is } \\
\text { named after a } \\
\text { former rector of } \\
\text { UGM to pay } \\
\text { respect. }\end{array}$ & $\begin{array}{l}\text { Name of an } \\
\text { official }\end{array}$ & $\begin{array}{c}1 \\
(0.7 \%)\end{array}$ & $\begin{array}{l}\text { Sign of a } \\
\text { place or a } \\
\text { street to } \\
\text { remember an } \\
\text { official or } \\
\text { figure }\end{array}$ & $\begin{array}{l}\text { To remember an } \\
\text { influential figure }\end{array}$ \\
\hline 10. & Abimanyu & $\begin{array}{l}\text { A shadow puppet } \\
\text { figure willing to } \\
\text { sacrifice himself } \\
\text { in the war for his } \\
\text { parents }\end{array}$ & $\begin{array}{l}\text { Name of a } \\
\text { shadow puppet } \\
\text { character }\end{array}$ & $\begin{array}{c}9 \\
(6.9 \%)\end{array}$ & $\begin{array}{l}\text { Sign of a role } \\
\text { model shadow } \\
\text { pupper } \\
\text { character }\end{array}$ & $\begin{array}{l}\text { To mark a role } \\
\text { model shadow } \\
\text { pupper character }\end{array}$ \\
\hline
\end{tabular}




\begin{tabular}{|c|c|c|c|c|c|c|}
\hline \multirow{2}{*}{ No. } & \multirow{2}{*}{$\begin{array}{l}\text { Street Name } \\
\text { Sample }\end{array}$} & \multirow{2}{*}{$\begin{array}{c}\text { Description of } \\
\text { the Historical } \\
\text { and Cultural } \\
\text { Analysis }\end{array}$} & \multicolumn{2}{|c|}{$\begin{array}{c}\text { Historical and Cultural } \\
\text { Category }\end{array}$} & \multirow{2}{*}{$\begin{array}{c}\text { Toponym } \\
\text { Motivation } \\
\text { and Purpose }\end{array}$} & \multirow{2}{*}{$\begin{array}{l}\text { Background of } \\
\text { Toponym } \\
\text { Motivation and } \\
\text { Purpose }\end{array}$} \\
\hline & & & $\begin{array}{c}\text { History and } \\
\text { Culture }\end{array}$ & Frequency & & \\
\hline 11. & Lobaningratan & $\begin{array}{l}\text { The suffix "-an" } \\
\text { means a place. } \\
\text { The word "laba" } \\
\text { means "good" or } \\
\text { "profit". } \\
\text { "Ningrat" refers } \\
\text { to the people in } \\
\text { the palace, but in } \\
\text { a more extensive } \\
\text { meaning, it does } \\
\text { not only apply in } \\
\text { the palace, but } \\
\text { also in the world } \\
\text { as "rat" means } \\
\text { "jagad" or "the } \\
\text { world." The } \\
\text { implication is } \\
\text { that if we do bad } \\
\text { deeds, we won't } \\
\text { gain profit, and } \\
\text { vice versa. The } \\
\text { misunderstanding } \\
\text { is that the word } \\
\text { "ningrat" only } \\
\text { applies in the } \\
\text { context of the } \\
\text { palace while in } \\
\text { fact the word } \\
\text { "rat" means "a } \\
\text { good way of } \\
\text { life." }\end{array}$ & Hope/expectation & $\begin{array}{c}9 \\
(6.9 \%)\end{array}$ & $\begin{array}{l}\text { Sign of a } \\
\text { particular } \\
\text { hope or } \\
\text { expectation }\end{array}$ & $\begin{array}{l}\text { To mark a } \\
\text { particular hope } \\
\text { or expectation }\end{array}$ \\
\hline 12. & Wijilan & $\begin{array}{l}\text { The suffix"-an" } \\
\text { means "a place," } \\
\text { while the word } \\
\text { "wijil" may refer } \\
\text { to the proximity } \\
\text { of the place to } \\
\text { the town square } \\
\text { as the word } \\
\text { means the gate of } \\
\text { the town square. }\end{array}$ & $\begin{array}{l}\text { State of a } \\
\text { physical } \\
\text { environment }\end{array}$ & $\begin{array}{c}2 \\
(1.5 \%)\end{array}$ & $\begin{array}{l}\text { Sign of a } \\
\text { particular } \\
\text { physical state } \\
\text { of the } \\
\text { environment }\end{array}$ & $\begin{array}{l}\text { To mark a } \\
\text { particular } \\
\text { physical state of } \\
\text { the environment }\end{array}$ \\
\hline 13. & $\begin{array}{l}\text { Mantrigawen } \\
\text { Lor }\end{array}$ & $\begin{array}{l}\text { Mantri is a clerk } \\
\text { type position } \\
\text { while gawe } \\
\text { means job. } \\
\text { Mantri's job is to } \\
\text { take care of other } \\
\text { palace workers } \\
\text { around the } \\
\text { palace. }\end{array}$ & Palace worker & $\begin{array}{c}1 \\
(0.7 \%)\end{array}$ & $\begin{array}{l}\text { Sign of the } \\
\text { residence of } \\
\text { the palace } \\
\text { clerks/officials }\end{array}$ & $\begin{array}{l}\text { To inform the } \\
\text { public on the } \\
\text { residence of the } \\
\text { palace } \\
\text { clerks/officials }\end{array}$ \\
\hline
\end{tabular}




\begin{tabular}{|c|c|c|c|c|c|c|}
\hline \multirow{2}{*}{ No. } & \multirow{2}{*}{$\begin{array}{l}\text { Street Name } \\
\text { Sample }\end{array}$} & \multirow{2}{*}{$\begin{array}{c}\text { Description of } \\
\text { the Historical } \\
\text { and Cultural } \\
\text { Analysis }\end{array}$} & \multicolumn{2}{|c|}{$\begin{array}{c}\text { Historical and Cultural } \\
\text { Category }\end{array}$} & \multirow{2}{*}{$\begin{array}{c}\text { Toponym } \\
\text { Motivation } \\
\text { and Purpose }\end{array}$} & \multirow{2}{*}{$\begin{array}{c}\text { Background of } \\
\text { Toponym } \\
\text { Motivation and } \\
\text { Purpose } \\
\end{array}$} \\
\hline & & & $\begin{array}{l}\text { History and } \\
\text { Culture }\end{array}$ & Frequency & & \\
\hline 14. & Patangpuluhan & $\begin{array}{l}\text { The name of the } \\
\text { palace guardian, } \\
\text { and the residence } \\
\text { of said guardian. } \\
\text { There used to be } \\
14 \text { guardian } \\
\text { names which } \\
\text { decreased into } 7 .\end{array}$ & Palace guardian & $\begin{array}{c}3 \\
(2.3 \%)\end{array}$ & $\begin{array}{l}\text { Sign of the } \\
\text { residence of } \\
\text { the palace } \\
\text { guards }\end{array}$ & $\begin{array}{l}\text { To inform the } \\
\text { public on the } \\
\text { residence of the } \\
\text { palace guards }\end{array}$ \\
\hline 15. & Namburan Lor & $\begin{array}{l}\text { "Namburan" } \\
\text { comes from the } \\
\text { word "tambur," } \\
\text { which is related } \\
\text { to gamelan, } \\
\text { sinden, and } \\
\text { traditional music } \\
\text { instruments. In } \\
\text { this case, the area } \\
\text { refers to the } \\
\text { residence of the } \\
\text { performer, not } \\
\text { the maker. When } \\
\text { they perform, } \\
\text { they live and stay } \\
\text { in the residence. }\end{array}$ & $\begin{array}{l}\text { Type of a music } \\
\text { instrument }\end{array}$ & $\begin{array}{c}1 \\
(0.7 \%)\end{array}$ & $\begin{array}{l}\text { Sign of the } \\
\text { residence of } \\
\text { gamelan } \\
\text { players }\end{array}$ & $\begin{array}{l}\text { To inform the } \\
\text { public on the } \\
\text { residence of } \\
\text { gamelan players }\end{array}$ \\
\hline 16. & $\begin{array}{l}\text { HKSN } \\
\text { Keparakan }\end{array}$ & $\begin{array}{l}\text { Short for the } \\
\text { "Friend Loyalty } \\
\text { Day." } \\
\text { "Keparakan" } \\
\text { may refer to the } \\
\text { word "marak" } \\
\text { which means the } \\
\text { number of } \\
\text { visitors. As the } \\
\text { palace was } \\
\text { located in the } \\
\text { west, those who } \\
\text { aimed to see the } \\
\text { Sultan or the } \\
\text { King were } \\
\text { allowed to stay in } \\
\text { houses which } \\
\text { served as a } \\
\text { transit point. }\end{array}$ & $\begin{array}{l}\text { Guest waiting } \\
\text { room }\end{array}$ & $\begin{array}{c}1 \\
(0.7 \%)\end{array}$ & $\begin{array}{l}\text { Sign of a } \\
\text { geographical } \\
\text { site in the } \\
\text { palace area }\end{array}$ & $\begin{array}{l}\text { To mark the } \\
\text { geographical } \\
\text { site of the palace } \\
\text { area }\end{array}$ \\
\hline
\end{tabular}




\begin{tabular}{|c|c|c|c|c|c|c|}
\hline \multirow{2}{*}{ No. } & \multirow{2}{*}{$\begin{array}{l}\text { Street Name } \\
\text { Sample }\end{array}$} & \multirow{2}{*}{$\begin{array}{c}\text { Description of } \\
\text { the Historical } \\
\text { and Cultural } \\
\text { Analysis }\end{array}$} & \multicolumn{2}{|c|}{$\begin{array}{c}\text { Historical and Cultural } \\
\text { Category }\end{array}$} & \multirow{2}{*}{$\begin{array}{c}\text { Toponym } \\
\text { Motivation } \\
\text { and Purpose }\end{array}$} & \multirow{2}{*}{$\begin{array}{l}\text { Background of } \\
\text { Toponym } \\
\text { Motivation and } \\
\text { Purpose }\end{array}$} \\
\hline & & & $\begin{array}{l}\text { History and } \\
\text { Culture }\end{array}$ & Frequency & & \\
\hline 17. & Siliran Lor & $\begin{array}{l}\text { "Silir" means } \\
\text { "breeze" or "cool } \\
\text { breeze." In the } \\
\text { northern part, } \\
\text { there are } \\
\text { traditional } \\
\text { Javanese music } \\
\text { instruments such } \\
\text { as gamelan, } \\
\text { klangenan, } \\
\text { langen astra, } \\
\text { langen arjan. } \\
\text { People who go } \\
\text { there may look } \\
\text { for entertainment } \\
\text { and peace, as } \\
\text { well as breeze } \\
\text { and cool air. }\end{array}$ & Sanctuary & $\begin{array}{c}1 \\
(0.7 \%)\end{array}$ & $\begin{array}{l}\text { Sign of a } \\
\text { sanctuary }\end{array}$ & $\begin{array}{l}\text { To mark the } \\
\text { geographical } \\
\text { site of the palace } \\
\text { area }\end{array}$ \\
\hline 18. & Magelang & $\begin{array}{l}\text { The way to } \\
\text { Magelang }\end{array}$ & $\begin{array}{l}\text { Close to } \\
\text { destination }\end{array}$ & $\begin{array}{c}3 \\
(2.3 \%)\end{array}$ & $\begin{array}{l}\text { Sign of a } \\
\text { certain } \\
\text { destination }\end{array}$ & $\begin{array}{l}\text { To mark the } \\
\text { direction of } \\
\text { certain region }\end{array}$ \\
\hline 19. & Lowanu & $\begin{array}{l}\text { Name of a place } \\
\text { located in the } \\
\text { west of Bagelan } \\
\text { consisting of } \\
\text { people who come } \\
\text { from the Lowanu } \\
\text { village in } \\
\text { Purworejo who } \\
\text { stay in the south } \\
\text { of the palace. } \\
\text { There were many } \\
\text { soldiers of } \\
\text { Diponegoro } \\
\text { which used the } \\
\text { place as the base } \\
\text { and in fact won a } \\
\text { war against the } \\
\text { Dutch there. It is } \\
\text { possible that they } \\
\text { resided after } \\
\text { winning the war. } \\
\text { Some of them } \\
\text { were relatives of } \\
\text { the Prince of } \\
\text { Diponegoro. }\end{array}$ & Origins & $\begin{array}{c}4 \\
(3.1 \%)\end{array}$ & $\begin{array}{l}\text { Sign of the } \\
\text { origins of a } \\
\text { place or street }\end{array}$ & $\begin{array}{l}\text { To mark the } \\
\text { origin of a place }\end{array}$ \\
\hline
\end{tabular}




\begin{tabular}{|c|c|c|c|c|c|c|}
\hline \multirow{2}{*}{ No. } & \multirow{2}{*}{$\begin{array}{l}\text { Street Name } \\
\text { Sample }\end{array}$} & \multirow{2}{*}{$\begin{array}{c}\text { Description of } \\
\text { the Historical } \\
\text { and Cultural } \\
\text { Analysis }\end{array}$} & \multicolumn{2}{|c|}{$\begin{array}{c}\text { Historical and Cultural } \\
\text { Category }\end{array}$} & \multirow{2}{*}{$\begin{array}{c}\text { Toponym } \\
\text { Motivation } \\
\text { and Purpose }\end{array}$} & \multirow{2}{*}{$\begin{array}{l}\text { Background of } \\
\text { Toponym } \\
\text { Motivation and } \\
\text { Purpose }\end{array}$} \\
\hline & & & $\begin{array}{l}\text { History and } \\
\text { Culture }\end{array}$ & Frequency & & \\
\hline 20. & Babaran & $\begin{array}{l}\text { The suffix "-an" } \\
\text { means "a place," } \\
\text { while "babaran" } \\
\text { means } \\
\text { "opening." The } \\
\text { area used to be a } \\
\text { vacant site which } \\
\text { begins to be } \\
\text { utilized as a new } \\
\text { residence area. }\end{array}$ & Village opening & $\begin{array}{c}1 \\
(0.7 \%)\end{array}$ & $\begin{array}{l}\text { Sign of a land } \\
\text { opening } \\
\text { activity }\end{array}$ & $\begin{array}{l}\text { To mark the } \\
\text { land opening or } \\
\text { a new village } \\
\text { opening event }\end{array}$ \\
\hline 21. & Sorogenen & $\begin{array}{l}\text { "Soro" means } \\
\text { "arrow" while } \\
\text { "genen" means } \\
\text { "fire." This refers } \\
\text { to the sacred } \\
\text { weapon given by } \\
\text { Indra to Arjuna, } \\
\text { both shadow } \\
\text { puppet } \\
\text { characters. } \\
\text { Another one of } \\
\text { their sacred } \\
\text { weapons also } \\
\text { becomes a } \\
\text { place's name, } \\
\text { namely Tegal } \\
\text { Gendu. }\end{array}$ & Weapon of war & $\begin{array}{c}1 \\
(0.7 \%)\end{array}$ & $\begin{array}{l}\text { Sign of a } \\
\text { sacred palace } \\
\text { weapon }\end{array}$ & $\begin{array}{l}\text { To mark a } \\
\text { particular } \\
\text { significant } \\
\text { sacred palace } \\
\text { weapon }\end{array}$ \\
\hline 22. & Tegal Gendu & $\begin{array}{l}\text { In Banyumas, a } \\
\text { region in Central } \\
\text { Java, "gendu" } \\
\text { refers to a joyful } \\
\text { friendly group } \\
\text { meeting. The } \\
\text { area is located } \\
\text { above the river, } \\
\text { in an upper part } \\
\text { of the area. It is } \\
\text { possible that } \\
\text { there was once a } \\
\text { wooden bridge } \\
\text { on the river } \\
\text { connecting the } \\
\text { area. It is similar } \\
\text { to the Gadjah } \\
\text { Wong river in the } \\
\text { western part of } \\
\text { the city that is } \\
\text { turned into a park } \\
\text { that visitors can } \\
\text { enjoy. }\end{array}$ & $\begin{array}{l}\text { Function of a } \\
\text { place }\end{array}$ & $\begin{array}{c}4 \\
(3.1 \%)\end{array}$ & $\begin{array}{l}\text { Sign of a } \\
\text { function of a } \\
\text { place }\end{array}$ & $\begin{array}{l}\text { To mark the } \\
\text { function of a } \\
\text { place }\end{array}$ \\
\hline 23. & Nitikan & $\begin{array}{l}\text { The suffix -an } \\
\text { means a place } \\
\text { while nitik is } \\
\text { related to a batik } \\
\text { making process. }\end{array}$ & Work activity & $2(1.5 \%)$ & $\begin{array}{l}\text { Sign of a work } \\
\text { activity in the } \\
\text { area }\end{array}$ & $\begin{array}{l}\text { To mark an } \\
\text { activity of Batik } \\
\text { making process }\end{array}$ \\
\hline
\end{tabular}




\begin{tabular}{|c|c|c|c|c|c|c|}
\hline \multirow{2}{*}{ No. } & \multirow{2}{*}{$\begin{array}{l}\text { Street Name } \\
\text { Sample }\end{array}$} & \multirow{2}{*}{$\begin{array}{c}\text { Description of } \\
\text { the Historical } \\
\text { and Cultural } \\
\text { Analysis }\end{array}$} & \multicolumn{2}{|c|}{$\begin{array}{c}\text { Historical and Cultural } \\
\text { Category }\end{array}$} & \multirow{2}{*}{$\begin{array}{c}\text { Toponym } \\
\text { Motivation } \\
\text { and Purpose }\end{array}$} & \multirow{2}{*}{$\begin{array}{l}\text { Background of } \\
\text { Toponym } \\
\text { Motivation and } \\
\text { Purpose }\end{array}$} \\
\hline & & & $\begin{array}{c}\text { History and } \\
\text { Culture }\end{array}$ & Frequency & & \\
\hline 24. & landung & $\begin{array}{l}\text { "Landung" } \\
\text { means "big } \\
\text { hearted," a } \\
\text { patient human } \\
\text { trait. }\end{array}$ & $\begin{array}{l}\text { Human } \\
\text { trait/character }\end{array}$ & $\begin{array}{c}2 \\
(1.5 \%)\end{array}$ & $\begin{array}{l}\text { Sign of a } \\
\text { human } \\
\text { trait/character }\end{array}$ & $\begin{array}{l}\text { To mark a } \\
\text { desired human } \\
\text { trait }\end{array}$ \\
\hline 25. & Mondoliko & $\begin{array}{l}\text { Derived from the } \\
\text { word "mandala." } \\
\text { In Javanese } \\
\text { attire, } \\
\text { "mondolan" } \\
\text { refers to the } \\
\text { round mandala } \\
\text { accessory or a } \\
\text { place. In the past, } \\
\text { "mondoliku" } \\
\text { refers to an } \\
\text { administrative } \\
\text { term of a region } \\
\text { equal to a district } \\
\text { or a subdistrict. }\end{array}$ & Name of a place & $\begin{array}{c}7 \\
(5.3 \%)\end{array}$ & $\begin{array}{l}\text { Sign of a } \\
\text { place or an } \\
\text { area }\end{array}$ & $\begin{array}{l}\text { To mark a place } \\
\text { or an area }\end{array}$ \\
\hline 26. & Warungboto & $\begin{array}{l}\text { The building in } \\
\text { the site uses red } \\
\text { bricks. }\end{array}$ & $\begin{array}{l}\text { Shape of a } \\
\text { building }\end{array}$ & $\begin{array}{c}1 \\
(0.7 \%)\end{array}$ & $\begin{array}{l}\text { Sign of a } \\
\text { particular } \\
\text { building }\end{array}$ & $\begin{array}{l}\text { To mark a } \\
\text { building once } \\
\text { exist in the area }\end{array}$ \\
\hline
\end{tabular}

\section{Street Names in Yogyakarta based on Historical and Cultural Studies}

It is important that the discussion begins by taking into account the notions of historical and cultural concepts. In this case, the historical and cultural concepts are the aspects that serve as the background of street naming process, whether from the event or mindset that lay the foundation.

According to Table 2, there are 130 street names that are studied in this research. Each of the street names is based on the history and culture of the people of Yogyakarta as the owners of the history and culture.

In this study, the street names involve a great and varied scope of history and culture. In a historical-cultural (anthropological) manner, the mindset of the Yogyakarta people in creating the street names can be viewed as a complex one as the language reflects the mind (Linda Wareing, 1999). The fact that history and culture are a big part of the street naming process implies that indeed the process reflects a more complex and expansive state of mind.

On the other hand, the street names discussed in this study is distinctive as there are no previous domestic or foreign studies on street names that are named after royalties. The findings reinstate that the issues of close relations in the palace or the public in general, the nation of Indonesia, are an important part in the life of the people of Yogyakarta in particular, and in Indonesia in general. In a study entitled "Self-Naming among Javanese People," Suharno (1987) mentioned 5 (five) types of naming, i.e. naming as an identity, hope, expectation, figure worship, and belief. Similarly, a study by Sumarsih classified the functions of naming into two, namely to pay respect to a certain figure, and on the basis of a profession.

This is supported by Suseno, who stated that onomastics may be derived from three basic principles of life, namely kinship, respect, and social harmony ethics (1988:83). Furthermore, street naming can be generated from the community's view of life, which can be defined as the descriptive belief on reality to the extent that the unity of the human provides a meaningful structure on the nature of the experience (Suseno, 19:32). It is also a framework of reference for humans to understand each element of their experience. The Javanese views of life are inseparabale among one another as they represent reality as one whole union. It must be understood as well that the view of life is not an abstract definition, yet serves to facilitate solving life's problems successfully. The pragmatic values of the Javanese people are to reach certain psychoogical state of serenity, peace, and inner balance.

In order to close the discussion on street naming, the Sapir-Wholf paradigm on the relation between language and culture and vice versa is highly relevant in regards to the main principle of language as the representation system of mind, behavior and culture pattern of a community. This confirms anthropolinguistics as an interdisciplinary study between language and culture and vice versa (Foley, 1997; Duranti, 1997). 
Language is bound to the cultural context. In other words, language is seen as an extension of culture. Indeed, according to the Sapir-Wholf hypothesis, each language represents a particular world of symbols which illustrate the reality of the mind, the inner experience, and the needs of the speakers. Language may influence the speakers in thinking and seeing the environment and surrounding nature to find the context of cultural outcomes such as street naming or the history of street naming. It is imperative that such event be traced into the conclusion that without language it is impossible to think, and that language influences perceptions and mindsets (Linda dan Wareing, 1999:32).

\section{Conclusion}

From the results and discussion of the study, it can be concluded that street naming in Yogyakarta is based on diverse/varied historical-cultural studies with a great scope, ranging from plants to the types of occupation of the Yogyakarta people.

\section{REFERENCES}

Bright, Brown. 1947. Studi es in Linguistics Relativity. in Headings in Social Psychology, E.E. Maccoby, dkk. (ed.). New York: Hold Rinehart and Winston.

Boas, Franz. 1964. Linguistics and Ethnology, in Dell Hymes (Ed.) Language In Cultural and Society. New York: Harper and Row.

Chaer, Abdul dan Leonie Agustina. 1995. Sosiolinguistik: Perkenalan Awal. Jakarta: Rineka Cipta.

Duranti, Alessandro. 1997. Linguistic Anthropology. Cambridge: Cambridge University Press.

Foley, Willian A. 1997. Anthropological Linguistics. Massachusetts: Balckwell Publisher Inc

Kahane, Henry R. 1960. Fifth International Conggres of Toponymy and Transactions by L. Cort: M. Graca Balnco A. Tovar. Speculum, Vol. 35, No. 3. Pp 440 -444.

Kaegi, Walter E. 2003. Byzantium and Arabs in Sixth Century, Vol. 2, part 1: Toponymy, monuments, Historical Geography and Frontier Studies by Irfan Shahid. Journal of the American Oriental Society, Vol. 123, No. 2. Pp $461-462$.

Koentjaraningrat. 1986. Pengantar Ilmu Antropologi. Jakarta: Aksara Baru.

Kramsch, Claire. 1998. Language and Culture. New York: Oxford University Press.

Linda and Wareing. 1999. Language, Society, and Power. New York: Routledge Palmer, Gary B. 1996. Toward A Theory of Cultural Linguistics. Austin: University of Texas Press.

Lyon, John. 1995. Pengantar Teori Semantik. Jakarta: Gramedia.

Oka, I.G.N. dan Suparno. 1994. Linguistik Umum. Jakarta: P4TK Dirjen Dikti.

Pradana, M. Satya. 2007. "Nama-Nama Jalan di Wilayah Krapyak Kulon”. Skripsi. Yogyakarta: Universitas Negeri Yogyakarta.

Prihadi. 2015. "The Anthroponym System Of Hamlets/ Villages in Yogyakarta Special Province (An Antropolinguistics Study)" Research \& Analysis Journal, Volume 1, Februari 2015, www.rajournals.in

Pusat Bahasa, 2015. Kamus Besar Bahasa Indonesia. Jakarta: Balai Pustaka.

Ramlan, M. 2001. Morfologi: Suatu Tinjauan Deskriptif. Yogyakarta: CV Karyono.

Salzman, Znedek. 1990. Toponymy of Bigar Region in the Romanian Banat.

Anthropological Linguistics, Vol. 32, No. 1/2. Pp. 139-148.

Sasangka, Sry Satriya Catur Wisnu. 2001. Paramasastra gagrag Anyar Bahasa Jawa. Jakarta: Yayasan Paralingua. Sibarani, M.S. 2004. Anthropolinguistic: Antropologi dan Linguistik. Medan: Poda.

Subroto, Edi D. 1989. Tata Bahasa Deskriptif Bahasa Jawa. Jakarta: Dikti.

Sundari, Wiwiek. 2008. "Proses Pembentukan Nama-Nama Makanan Berbahasa Inggris di Restoran di Simpang Lima”. Thesis. Semarang: Universitas Diponegoro Semarang.

Suryatna, Ayat. 1996. Antropologi. Bandung: Ganesha Exact.

Verhaar, P.W.J. 2004. Azas-azas Linguistik Umum. Yogyakarta: Gadjah Mada University Press.

Prihadi is a doctor of Indonesian Language and Literature Education in Yogyakarta State University. His career as lecturer has started since 1990, focuses in Linguistics specifically in Antropolinguistic. He gained his master degree in Education at Gadjah Mada University in 1999 and his doctoral degree at Sebelas Maret University, Surajkarta in 2015. His dissertation work involved anthropolinguistic studies entitle " The system Toponimi Hamlets and Villages in Yogyakarta special Region (A study Antrhopolinguistic) that has published in several Ienternational and national journal articles.

Ari Listiyorini, M.Hum. A lecturer in the Departement of Indonesian Language and Literature Education, Faculty of Languages and Arts, Yogyakarta State University since 1999. Her area of ekspertise is Linguistics. Her undergraduate degree (S1) was taken at UGM, in 1998, and her master degree (S2) was also taken at UGM in 2003. She is currently pursuing doctora ldegree (S3) at UGM. Her research articles have been published in national journals. 